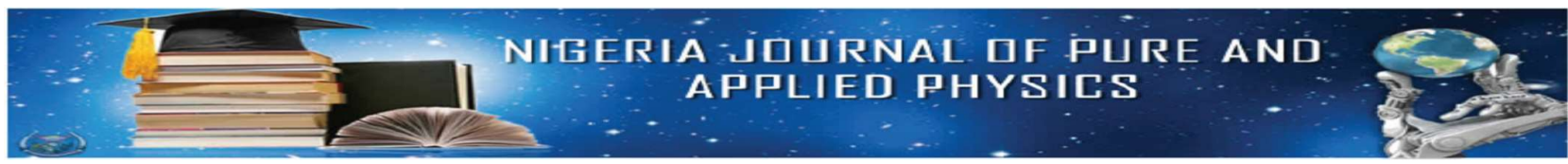

Nigeria Journal of Pure \& Applied Physics, Vol. 9, No. 1, pages 6-10, 2019

\title{
Soil-to-maize Transfer Factor of Natural Radionuclides in a Tropical Ecosystem of Nigeria
}

\author{
N. E. Adesiji ${ }^{\dagger, 1,2}$, J. A. Ademola ${ }^{2}$ \\ ${ }^{1}$ Department of Physics, Federal University of Technology, Akure, Ondo State, Nigeria \\ ${ }^{2}$ Department of Physics, University of Ibadan, Ibadan, Oyo State, Nigeria (jaaademola@yahoo.com ) \\ †Corresponding Author's Email: adesijinkiruka@gmail.com, neadesiji@,futa.edu.ng
}

\begin{abstract}
Soil-to-plant transfer factor (TF) is a parameter utilized in predicting the accumulation of radionuclides in the plant system. Virgin soil from an uncultivated area and tailings from an abandoned tin mining site were used to formulate three soil groups. Group A (virgin soil only), group B (tailings only) and group C (equal mixture by mass of the virgin soil and tailings). Pot experiments were performed using the soil groups to determine the transfer factors of ${ }^{40} \mathrm{~K},{ }^{238} \mathrm{U}$ and ${ }^{232} \mathrm{Th}$ in maize (Zea mays L.) plants for the tropical ecosystem of Nigeria. The activity concentrations of ${ }^{40} \mathrm{~K},{ }^{238 \mathrm{U}}$ and ${ }^{232} \mathrm{Th}$ in the soil groups and the maize plant compartments (seed, stem, leaf and root) were determined using $\mathrm{NaI}(\mathrm{Tl})$ gamma-detector. The geometric mean (GM) of the TF values for ${ }^{40} \mathrm{~K},{ }^{238} \mathrm{U}$ and ${ }^{232} \mathrm{Th}$ respectively ranged from 0.02 to 0.27 , below detectable limit (BDL) to 0.008 and 0.01 to 0.09 in the in the seeds; 0.04 to 1.74 , BDL to BDL and 0.01 to 0.29 in the stems; 0.03 to 0.93 , BDL to 0.33 and 0.02 to 0.08 in the leaves and 0.03 to $1.29,0.05$ to 0.38 and 0.08 to 0.41 in the roots. Potassium- 40 had the highest TF values and exhibited the plant accumulation strategy for all the plant compartments. The stem samples had the highest TF for ${ }^{40} \mathrm{~K}$ and BDL values for ${ }^{238} \mathrm{U}$ for all the soil groups. Significance differences were observed only in the accumulation of ${ }^{40} \mathrm{~K}$ and ${ }^{232} \mathrm{Th}$ across the soil group.
\end{abstract}

Keywords: Radioactivity, potassium, mining, Gamma-ray detectors, calibration

\section{INTRODUCTION}

Exposure of humans to ionizing radiation of natural and anthropogenic origin is inevitable. The two main contributors to radiation of natural origin are the high energy cosmic ray particles striking the air molecules in the atmosphere and primordial radioactive nuclides in naturally occurring radioactive substances existing in the earth crust $[1,2]$. Through weathering of the earth crust, primordial radionuclides enter the soil [3]. The radionuclides in the soil are taken up by plants via their root, and can be transferred to human when crops harvested from such plants are consumed, leading to internal exposure to ionizing radiations. Radionuclides ingested through food consumption are major radiation pathways for long term health considerations and contribute significantly to the average radiation doses to various organs and tissues in the human body [4].

The uptake of radionuclides from the soil by plants, normally expressed as soil-to-plant transfer factor (TF), transfer coefficient (TC) or concentration ratio (CR), is defined as the ratio of the activity concentration in a plant part (in $\mathrm{Bq} \mathrm{kg}^{-1}$ dry weight) to the activity concentration in the soil (in $\mathrm{Bq} \mathrm{kg}^{-1}$ dry weight) $[5,6]$. The TF is essential for estimating and predicting the radionuclide concentration in agricultural crops so as to calculate radiological dose impact to human beings when the plants are ingested $[7,8]$. So many factors have been identified to affect the accumulation of radionuclides in plants. These factors include concentration of radionuclides in soil, soil $\mathrm{pH}$, climate, speciation of radionuclides in soil solution, organic content of the soil, soil type etc. [9]. The uptake of the radionuclides are also regulated by processes that change the mobility of the physicochemical forms of the radionuclides [10]. The transfer of radionuclide from soil to plant is also element specific, as a result, root uptake of all the isotopes of a given element is identical $[11,12]$. These various factors introduce great variability in the values of the TF, spanning from one to two orders of magnitude for each element in farm crops [13]. The biological variability in plants of different varieties and species has the likelihood of introducing variability in TF [13]. These variability is however reduced when plant group or species are taken into consideration [14]. Thus, there is need to categorise the TF parameter according to plant type.

Technical Report Series No 472 (TRS-472) of IAEA [13] compiled data on radionuclide transfer factors for temperate and tropical ecosystem, sufficient data were not obtained for most radionuclides for some plants, especially for the tropical region. For instance, no $T F$ value of ${ }^{40} \mathrm{~K}$ was reported for any compartment of maize plant, whereas TFs for ${ }^{238} \mathrm{U}$ and ${ }^{232} \mathrm{Th}$ were reported only for maize grains. The TFs on different soil types were also not adequately reported, due to unavailability of data [13]. There is also a dearth of data on the TF of radionuclides of common crops (cassava, cowpea, maize, rice)in Nigeria. This gap was observed in the IAEA [13], as no data was obtained from any African country for the reported TF values for the tropical ecosystem. Hence, the aim of this work, which is to determine the TF of maize plant for the tropical ecosystem of Nigeria for different soil groups. Maize (Zea may L.) 
also known as corn is a major staple food in Nigeria because of its starch content, having a frequency of consumption of $20.1 \%$ in Nigeria [15].

\section{MATERIALS AND METHODS}

\subsection{Sample collection, experiment and preparation}

Samples of tailings were collected from an abandoned tin mining site in Jos because of the high activity concentration of ${ }^{40} \mathrm{~K},{ }^{238} \mathrm{U}$ and ${ }^{232} \mathrm{Th}$ that has been reported in literature [4,16-22]. The geology of the study area was extensively discussed [21]. Samples of virgin soil from uncultivated area were also collected. Studies of this nature add a given quantity of the radionuclide of interest to soil, because of the non-availability of radionuclides in the laboratory, samples of tailings collected were added to some portion of the virgin soil to create different activity concentrations of ${ }^{40} \mathrm{~K},{ }^{238} \mathrm{U}$ and ${ }^{232} \mathrm{Th}$. Three groups of soil for planting were prepared from the tailings and the virgin soil. Group A was made up of soil sample from the virgin land only, group B was made up of the tailings only and group $C$ was made of equal ratio by dry mass of the tailings and virgin soil. The mixture of soil samples from the virgin area and the tailings is to create a different activity concentration. The radioactivity concentrations of ${ }^{40} \mathrm{~K},{ }^{238} \mathrm{U}$ and ${ }^{232} \mathrm{Th}$ were measured for ten samples from each of the soil groups before planting. Ten planting pots, each of $29 \mathrm{~cm}$ height and $23 \mathrm{~cm}$ diameter, were prepared from each of the soil group. Maize seeds (code: TZPB), collected from Institute of Agricultural Research and Training (IAR\&T) Ibadan, Nigeria were planted in each pot. The pots were placed in an open space where they were exposure to adequate sunlight and were watered daily until maturity at about four months.

Fertilizer was not applied to the plant, this is to remove the complexity that the application of fertilizer might introduce, since it has been established that most fertilizer contains radionuclides in appreciable quantity [23]. At maturity, the crops and entire plant system of the survived plants were harvested, thoroughly washed with clean water, labeled and dried separately at room temperature. The plant system was then separated into the plant compartments (seed, stem, leaves, and roots). Each sample of the plant compartment was then oven dried until it attains a constant mass. The samples were separately grinded, weighted, packed in a cylindrical container of height $8.0 \mathrm{~cm}$ and diameter $7.0 \mathrm{~cm}$ and sealed to make it air-tight. The sealed samples were labeled and stored for more than four weeks in order to allow for the attainment of secular equilibrium of ${ }^{238} \mathrm{U}$ and ${ }^{232} \mathrm{Th}$ with their respective progeny [23].

\subsection{Activity measurement and transfer factor}

The counting system used was a $7.6 \mathrm{~cm} \times 7.6 \mathrm{~cm} \mathrm{NaI(T1)}$ scintillation detector by Bicron (Model No. 1002 series), sealed with a photo multiplier tube and connected through a preamplifier base to a Canberra series 10-plus multichannel analyser (MCA). Single calibrated gamma sources $\left({ }^{22} \mathrm{Na},{ }^{137} \mathrm{Cs}\right.$, and $\left.{ }^{60} \mathrm{Co}\right)$ from the Nucleus Inc., Oak Ridge, TN, USA and reference sources (RGK-1, RGU-1, RGTh-1) from the International Atomic Energy Agency (IAEA) were used for the energy calibration of the spectrometer. Calibration was done for gamma energy range of 0.511

$\mathrm{MeV}$ to $2.615 \mathrm{MeV}$. In order to quantify the radionuclides present in the samples, efficiency calibration was carried out using reference sources; ENV 950050 prepared from Rocketdyne laboratories, Canoga Park, California, USA and IAEA 152 for the soil and food matrices, respectively.

The samples were placed symmetrically on top of the detector and measured for a counting time of 10 hours. The net area under the corresponding peaks in the energy spectrum was computed by subtracting counts due to Compton scattering of higher peaks and other background sources from the total area of the peaks [20]. From the net area, the activity concentrations $\mathrm{C}$ in the samples were obtained using equation 1 [24-26];

$$
C=\frac{A}{t E_{p} Y m}
$$

where $A$ is the net area under the photopeak, $t$ is the counting time $36,000 \mathrm{~s}(10 \mathrm{hrs}), E_{p}$ is the detection efficiency, $Y$ is the gamma yield and $m$ is the mass of the samples in $\mathrm{kg}$. The $1.460 \mathrm{MeV}$ photopeak was used for the measurement of ${ }^{40} \mathrm{~K}$ while the $1.760 \mathrm{MeV}$ photopeak from ${ }^{214} \mathrm{Bi}$ and the $2.614 \mathrm{MeV}$ photopeak from ${ }^{208} \mathrm{Tl}$ were used for the measurement of ${ }^{238} \mathrm{U}$ and ${ }^{232} \mathrm{Th}$, respectively. The lower limit of Detection (LLD) of the detector at $95 \%$ level of confidence for each of the radionuclide was calculated from the background count. A total of thirty (30) soil samples and ninety-two (92) maize compartment samples were analysed. Samples that have activity concentrations equal of less than the LLD are termed below detectable limit (BDL).

Table 1: Soil properties of the soil groups [29]

\begin{tabular}{cccccccc}
\hline $\mathrm{S} / \mathrm{N}$ & Soil ID & $\mathrm{pH}$ & Organic Matter $(\mathrm{g} / \mathrm{kg})$ & Clay $(\mathrm{g} / \mathrm{kg})$ & Silt $(\mathrm{g} / \mathrm{kg})$ & Fine Sand $(\mathrm{g} / \mathrm{kg})$ & Soil classification \\
\hline 1 & Group A & 6.63 & 22.42 & 134 & 114 & 752 & Sandy loam \\
2 & Group B & 6.83 & 6.84 & 34 & 14 & 925 & Sand \\
3 & Group C & 6.86 & 12.92 & 74 & 74 & 852 & Loamy sand \\
\hline
\end{tabular}


Adesiji and Ademola: Soil-to-maize transfer factor of natural radionuclides...

Table 2: The activity concentrations (Mean $\pm \mathrm{STD}$ ) of ${ }^{40} \mathrm{~K},{ }^{238} \mathrm{U}$ and ${ }^{232} \mathrm{Th}$ in $\mathrm{Bq} \cdot \mathrm{kg}^{-1}$ for the soil samples

\begin{tabular}{lcllc}
\hline Sample & Number of Samples & \multicolumn{1}{c}{${ }^{40} \mathrm{~K}$} & ${ }^{238} \mathrm{U}$ & ${ }^{232} \mathrm{Th}$ \\
\hline Group A & 10 & $374.01 \pm 590.51$ & $242.13 \pm 429.10$ & $1776.08 \pm 4164.89$ \\
Group B & 10 & $5008.18 \pm 2427.16$ & $2354.98 \pm 1260.39$ & $26211.90 \pm 7178.22$ \\
Group C & 10 & $1573.93 \pm 3123.65$ & $2763.90 \pm 2345.77$ & $15294.77 \pm 6924.46$ \\
\hline
\end{tabular}

Table 3: The activity concentrations in Bq kg-1 (Mean \pm STD) and transfer factors $(\mathrm{GM} \pm \mathrm{GSD})$ of ${ }^{40} \mathrm{~K}$, ${ }^{238} \mathrm{U}$ and ${ }^{232} \mathrm{Th}$ in the compartments of maize plant

\begin{tabular}{|c|c|c|c|c|c|c|c|c|}
\hline \multirow{2}{*}{$\begin{array}{l}\text { Soil } \\
\text { group }\end{array}$} & \multirow{2}{*}{$\begin{array}{l}\text { Plant } \\
\text { parts }\end{array}$} & \multirow{2}{*}{ 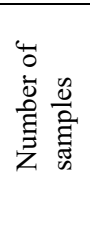 } & \multicolumn{3}{|c|}{ Activity concentration $\left(\mathrm{Bq} \mathrm{kg}^{-1}\right)$} & \multicolumn{3}{|c|}{ Transfer factor } \\
\hline & & & ${ }^{40} \mathrm{~K}$ & ${ }^{238} \mathrm{U}$ & ${ }^{232} \mathrm{Th}$ & ${ }^{40} \mathrm{~K}$ & ${ }^{238} \mathrm{U}$ & ${ }^{232} \mathrm{Th}$ \\
\hline \multirow{5}{*}{ 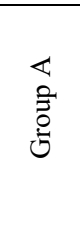 } & Seed & 7 & $105.43 \pm 37.21$ & BDL & $318.46 \pm 499.96$ & $0.27 \pm 1.36$ & BDL & $0.09 \pm 2.78$ \\
\hline & Stem & 7 & $685.08 \pm 245.70$ & BDL & $828.87 \pm 783.01$ & $1.74 \pm 1.39$ & BDL & $0.29 \pm 3.01$ \\
\hline & Leaf & 7 & $371.13 \pm 137.34$ & $80.06 \pm 5.60$ & $304.31 \pm 221.50$ & $0.93 \pm 1.14$ & $0.33 \pm 1.05$ & $0.08 \pm 3.70$ \\
\hline & Root & 7 & $561.34 \pm 372.74$ & $245.47 \pm 322.23$ & $1065.80 \pm 1035.16$ & $1.29 \pm 1.71$ & $0.38 \pm 5.18$ & $0.41 \pm 2.43$ \\
\hline & Seed & 8 & $127.04 \pm 115.46$ & $25.58 \pm 23.08$ & $1098.08 \pm 854.13$ & $0.02 \pm 2.14$ & $0.008 \pm 2.00$ & $0.03 \pm 2.04$ \\
\hline \multirow{3}{*}{ 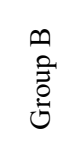 } & Stem & 8 & $299.90 \pm 198.23$ & BDL & $485.51 \pm 276.73$ & $0.04 \pm 2.22$ & BDL & $0.02 \pm 1.97$ \\
\hline & Leaf & 8 & $190.83 \pm 165.21$ & $\mathrm{BDL}$ & $826.37 \pm 1182.03$ & $0.03 \pm 2.04$ & BDL & $0.02 \pm 2.35$ \\
\hline & Root & 8 & $243.77 \pm 252.77$ & $367.19 \pm 442.38$ & $3831.23 \pm 2282.00$ & $0.03 \pm 2.41$ & $0.17 \pm 2.45$ & $0.13 \pm 1,72$ \\
\hline \multirow{4}{*}{\begin{tabular}{l}
0 \\
$\vdots$ \\
$\vdots$ \\
\multirow{3}{*}{}
\end{tabular}} & Seed & 8 & $283.50 \pm 325.77$ & BDL & $433.72 \pm 671.35$ & $0.12 \pm 2.49$ & BDL & $0.01 \pm 4.00$ \\
\hline & Stem & 8 & $328.59 \pm 185.61$ & $\mathrm{BDL}$ & $184.49 \pm 81.32$ & $0.15 \pm 2.88$ & $\mathrm{BDL}$ & $0.01 \pm 1.40$ \\
\hline & Leaf & 8 & $349.48 \pm 477.59$ & $18.08 \pm 9.53$ & $238.05 \pm 64.64$ & $0.13 \pm 2.61$ & $0.006 \pm 1.48$ & $0.02 \pm 1.27$ \\
\hline & Root & 8 & $298.94 \pm 504.20$ & $185.36 \pm 120.82$ & $1648.80 \pm 913.12$ & $0.08 \pm 3.31$ & $0.05 \pm 2.37$ & $0.08 \pm 2.59$ \\
\hline
\end{tabular}

The $\mathrm{TF}$ of ${ }^{40} \mathrm{~K},{ }^{238} \mathrm{U}$ and ${ }^{232} \mathrm{Th}$ for all the maize compartment samples were calculated using equation 2 [12, 27];

$$
T F=\frac{\text { Activity } \text { concentration of plant }\left(\mathrm{Bq} \mathrm{kg}^{-1}, \text { dry weigth }\right)}{\text { Activity concentration of soil }\left(\mathrm{Bq} \mathrm{kg}^{-1}, \text { dry weigth }\right)}
$$

The geometric mean (GM) and geometric standard deviation (GSD) were used to summarise the data of the TF.

\section{RESULTS AND DISCUSSION}

The soil properties of the soil groups are presented in Table 1 . The three soil groups are slightly acidic with $\mathrm{pH}$ ranging from 6.63 (group $\mathrm{A}$ ) to 6.86 (group $\mathrm{C}$ ). The organic matter content ranged from 6.84 (group B) to 22.42 (group A) $\mathrm{g} / \mathrm{kg}$. The clay and silt contents ranged from 34 to 134 $\mathrm{g} / \mathrm{kg}$ and from 14 to $114 \mathrm{~g} / \mathrm{kg}$, respectively while the fine sand content ranged from 752 to $925 \mathrm{~g} / \mathrm{kg}$. Table 2 gives the mean activity concentrations of ${ }^{40} \mathrm{~K},{ }^{238} \mathrm{U}$ and ${ }^{232} \mathrm{Th}$ of the soil groups. Thorium-232 had the highest activity concentration for all the soil groups. The highest and least activity concentration of ${ }^{40} \mathrm{~K}$ and ${ }^{232} \mathrm{Th}$ were observed in group B and group A, respectively. While for ${ }^{238} \mathrm{U}$, the highest and least activity concentrations were observed in group $\mathrm{C}$ and group $\mathrm{A}$, respectively.

The mean activity concentration of ${ }^{40} \mathrm{~K}$ in Bq. $\mathrm{kg}^{-1}$ for the maize compartments (table 3 ) ranged from 105.43 in maize seeds harvested from soil group A to 685.08 in stem sample harvested from soil group $\mathrm{A},{ }^{238} \mathrm{U}$ ranged from BDL (seed and stem samples from groups $\mathrm{A}$ and $\mathrm{C}$; stem and leaf sample for group B) to $367.19 \mathrm{~Bq} \cdot \mathrm{kg}^{-1}$ in root sample harvested from soil group $B$ while ${ }^{232} \mathrm{Th}$ ranged from 184.49 in the stem samples harvested from soil group $\mathrm{C}$ to $1648.80 \mathrm{~Bq} \cdot \mathrm{kg}^{-1}$ in the root sample harvested from soil 
group C. The geometric mean (GM) of the TF values for ${ }^{40} \mathrm{~K}$ (table 3 ) in the plant compartments from group $\mathrm{A}$ varied from 0.27 (seed) to 1.74 (stem); for group B it varied from 0.02 (seed) to 0.04 (stem) and for group C, it varied from 0.08 (root) to 0.15 (stem). A two-way ANOVA performed on the data showed significant difference in the geometric means of the TF values of ${ }^{40} \mathrm{~K}$ in soil groups $\mathrm{B}$ and $C(p<0.05)$ as well as between the stem and seed samples $(p=0.01)$. Potassium-40 had the highest TF values across the samples of the maize compartments except for the seed and root samples harvested from soil group B. It has been established that the uptake of radionuclides from soil is element specific and is also facilitated by the radionuclide similarity to plant essential nutrient $[9,12]$, therefore the high values observed for the ${ }^{40} \mathrm{~K}$ could be as a result of its similarity to the stable potassium which is one the essential elements for proper plant growth. According to [28], potassium activates the enzymes that maintain the turgidity of the cells, this could be the reason for the highest values of ${ }^{40} \mathrm{~K}$ observed in the stem samples for each of the group, since the cell around the stem need to be turgid enough to carry the weight of the maize cobs.

The GM of the TF of ${ }^{238} \mathrm{U}$ (table 3) in the plant compartments ranged from BDL (seed and stem) to 0.38 (root) for group A; BDL (stem and leaf) to 0.17 (root) for group B and from BDL (seed and stem) to 0.05 (root) for group C. No significant difference was observed for ${ }^{238} \mathrm{U}$ for the soil groups $(\mathrm{p}=0.40)$ and for the plant compartments $(\mathrm{p}=0.46)$. Uranium-238 had the least $\mathrm{TF}$ in most of the samples. The TF of ${ }^{238} \mathrm{U}$ for all the stem samples harvested from the three soil groups were BDL.

For ${ }^{232} \mathrm{Th}$ the GM of the TF (table 3) in the plant compartments ranged from 0.08 (leaf) to 0.41 (root) for group A; 0.02 (stem and leaf) to 0.13 (root) for group B and from 0.01 (seed and stem) to 0.08 (root). There was significant difference in the geometric mean of the TF values of ${ }^{232} \mathrm{Th}$ between group $\mathrm{A}$ and $\mathrm{B}(\mathrm{p}<0.05)$, and for soil group $A$ and $C(p<0.05)$ but the difference between group $B$ and $C$ was not significant $(\mathrm{p}=0.83)$.

Sheppard and Evenden et al., 1988 observed that the TF of radionuclides decreased as the concentration of the radionuclides in the soil increased was termed the plant accumulation strategy. Potassium-40 maintained the plant accumulation strategy for each plant compartment across the soil group, but this was not observed for ${ }^{238} \mathrm{U}$ and ${ }^{232} \mathrm{Th}$. Comparing the TF of ${ }^{238} \mathrm{U}$ for maize seed to the TF values of IAEA, 2010 (table 4), a difference of one order of magnitude was observed for ${ }^{238} \mathrm{U}$ while that of ${ }^{232} \mathrm{Th}$ had two orders of magnitude difference.

\section{Conclusion}

The TF values of ${ }^{40} \mathrm{~K},{ }^{238} \mathrm{U}$ and ${ }^{232} \mathrm{Th}$ in maize plant compartments were evaluated in this work using activity concentrations of each radionuclide in the plant compartment and soil samples. The plant accumulation strategy was observed only for ${ }^{40} \mathrm{~K}$. Potassium-40 had the highest TF when compared with the TF of ${ }^{238} \mathrm{U}$ and ${ }^{232} \mathrm{Th}$. For all the soil groups, the stem compartment had the highest TF for ${ }^{40} \mathrm{~K}$ and BDL values for ${ }^{238} \mathrm{U}$. Uranium-238 had most of the least TF values.

\section{REFERENCES}

[1] International Commission on Radiological Protection (2007). The 2007 Recommendations of the International Commission on Radiological Protection. Annals of ICRP Publication 103

[2] United Nations Scientific Committee on the Effects of Atomic Radiation (UNSCEAR). 2008. Sources and effects of ionizing radiation. Volume 1. UNSCEAR 2008 report to the general assembly with scientific annexes.

[3] Alharbi, A. and El-Taber, A. 2013. A study of the transfer factor of radionuclides from soil to plant. Life Science Journal 2: 532- 539.

[4] Jibiri, N.N., Farai, I.P. and Alausa, S.K. 2007. Estimation of annual effective dose due to natural radioactive elements in ingestion of foodstuffs in tin mining area of Jos-Plateau, Nigeria. Journal of Environmental Radioactivity 94: 31-40.

[5] Ehlken, S. and Kirchner, G. 2002. Environmental process affecting plant root uptake of radioactive trace elements and variability of transfer factor data: a review.

Table 4: Comparison of the TF values obtained in the present work and the TF values from IAEA 2010 of the cereals (maize) for the tropical region

\begin{tabular}{|c|c|c|c|c|c|c|}
\hline Plant part & Soil type & $\begin{array}{l}\text { Nos. of } \\
\text { data }(\mathrm{N})\end{array}$ & ${ }^{40} \mathrm{~K}$ & ${ }^{238} \mathrm{U}$ & ${ }^{232} \mathrm{Th}$ & Reference \\
\hline \multirow{3}{*}{$\begin{array}{l}\text { Maize } \\
\text { grain }\end{array}$} & All & 2 & - & $8.7 \times 10^{-2}$ & - & IAEA, 2010 \\
\hline & Loam & 6 & - & - & 1.9 & IAEA, 2010 \\
\hline & Sand & 1 & - & $1.5 \times 10^{-3}$ & - & IAEA, 2010 \\
\hline \multirow{3}{*}{$\begin{array}{l}\text { Maize } \\
\text { seeds }\end{array}$} & Sandy loam & 7 & $2.7 \times 10^{-1}$ & BDL & $9.0 \times 10^{-2}$ & Present study \\
\hline & Sand & 8 & $2.0 \times 10^{-2}$ & $8.0 \times 10^{-3}$ & $3.0 \times 10^{-2}$ & Present study \\
\hline & Loamy sand & 8 & $1.2 \times 10^{-1}$ & BDL & $1.0 \times 10^{-2}$ & Present study \\
\hline
\end{tabular}


Journal of Environmental radioactivity 58: $97-112$.

[6] Baeza, A., Guillen, J. and Bernedo, J.M. 2005. Soilfungi transfer coefficients: importance of the location of mycelium in soil and of the differential availability of radionuclides in soil fractions. Journal of Environmental Radioactivity 81: $89-106$.

[7] Chakraborty, S.R., Azim, R, Rahman A.K.M.R. and Sarker, R. 2013. Radioactivity concentrations in soil and transfer factors of radionuclides from soil to grass and plants in the Chittagong city of Bangladesh. Journal of Physical Science 21(1): 95 - 113.

[8] Abiama, P.E., Ben-Bolie, G.H., Amechmachi, N., Najid, F., Khoukhi, T.E and Ateba, P.O. 2012. Annual intake of ${ }^{226} \mathrm{Ra},{ }^{228} \mathrm{Ra}$ and ${ }^{40} \mathrm{~K}$ in staple foodstuffs from a high background radiation area in the southwest region of Cameroon. Journal of Environmental Radioactivity 110: 59 -62 .

[9] Golmakani, S., Moghaddam, M.V. and Hosseini, T. 2008. Factors affecting the transfer of radionuclides from the environment to plants. Radiation Protection Dosimetry DOI: $10.1093 / \mathrm{rpd} / \mathrm{ncn} 063$

[10] Rachkova, N.G., Shuktomova, I.I. and Taskaev, A.I. 2010. The state of natural radionuclides of uranium, radium and thorium in soils. Eurasian Soil Science 43: 651-658.

[11] Sheppard, S.C. and Evenden, W.G. 1988. Critical compilation and review of plant/soil concentration ratios for Uranium, thorium and lead.. Journal of Environmental Radioactivity 8: 255-285.

[12] Tome, F.V., Rodriguez, M.P.B. and Lozano, J.C. 2003. Soil-to-plant transfer factors for natural radionuclides and stable elements in a Mediterranean area. Journal of Environmental Radioactivity. 65: 161 - 175.

[13] International Atomic Energy Agency IAEA (2010). Handbook of parameter values for the prediction of radionuclide transfer in terrestrial and freshwater environment. Technical Report Series No. 472.

[14] Valesco, H., Ayub, J.J. and Sansone, U. 2009. Influence of crop types and soil properties on radionuclide soil-to-plant transfer factors in tropical and subtropical environments. Journal of Environmental Radioactivity. 100: $733-738$.

[15] International Institute of Tropical Agriculture (IITA). 2004. Nigeria food consumption and nutrition survey 2001-2003, summary.

[16] Oresegun, M.O., Babalola, I.A. 1988. Annual indoor dose burden estimates in dwellings built in Nigeria with radioactive U-Th rich tailings. Proceedings of an International Conference of Radiation Protection in Nuclear Energy organised by the International Atomic Energy Agency in Sydney.159-166.
[17] Oresegun, M.O., Babalola, I.A. 1990. Occupational radiation exposure associated with milling of Th-U rich $\mathrm{Sn}$ in Nigeria. Health Physics 58: 213-215.

[18] Oresegun, M.O., Babalola, I.A. 1993. The environmental gamma radiation level of Jos, Nigeria. Nigerian Journal of Science 27: 263-268.

[19] Arogunjo, A.M., Ofuga, E.E., Afolabi, M.A. 2005. Levels of natural radionuclides in some Nigerian cereals and tubers. J. Environ. Radioact. 82, 1-6.

[20] Jibiri, N.N., Alausa, S.K. and Farai, I.P. 2009. Assessment of ecternal and internal doses due to farming in high background radiation area in the old tim mining localities in Jos-plateau, Nigeria. Radioprotection 44: 139 151.

[21] Ademola, J.A. 2008. Exposure to high background radiation level in the tin mining area of Jos Plateau, Nigeria. Journal of Radiological Protection 28: 93-99.

[22] Olise, F.S., Owoade, O.K., Olaniyi, H.B. 2011. Radiological indices of technologically enhanced naturally occuring radionuclides: a PIXE approach. Journal of Radiological Protection 31: 255-264.

[23] Ahmed, N.K. and El-Arabi, A.G.M. 2005. Natural radioactivity in farm soil and phosphate fertilizer and its environmental implications in Qena governorate, Upper Egypt. Journal of Environmental Radioactivity 84(1): 5164.

[24] Olomo, J.B., Akinloye, M.K., Balogun, F.A. 1994. Distribution of gamma emitting-natural radionuclides in soils and water around nuclear research establishments, IleIfe, Nigeria. Nuclear Instruments and Methods in Physics Research Section A 353, 553-557.

[25] Akinloye, M.K. and Olomo, J.B. 2000. The measurement of the natural radioactivity in some tubers cultivated in farmlands within Obafemi Awolowo University Ile-Ife, Nigeria. Nigerian Journal of Physics 12: 60-63.

[26] Ademola, J.A. and Okpalaonwuka, N.E. 2010. Occupational exposure to natural radionuclides due to mining activities in Ibadan, Southwestern Nigeria. Radioprotection 45:43-53.

[27] Beresford, N.A., Wright, S.M., Barnett, C.L., Golikov, V., Shutov, V. and Kravtsova, O. 2005. Approaches to estimating the transfer of radionuclides to Arctic biota. Radioprotection Suppl. 40: S285-S290.

[28] Prajapati, K. and Modi, H.A. 2012. The importance of potassium in plant growth- a review. Indian Journal of Plant Science 1: 177-186.

[29] Adesiji, N.E. and Ademola, J.A. 2015. Soil-tocassava plant transfer factor of natural radionuclides on a mining impacted soil in a tropical ecosystem of Nigeria. Journal of Environmental Radioactivity 201: 1-4. 